\title{
Vključenost lokalne skupnosti v pripravo smernic za urbanistično oblikovanje na območjih kulturne dediščine: primer Burse v Turčiji
}

$\mathrm{V}$ zadnjih letih so centralna vlada in lokalne uprave $\mathrm{v}$ Turčiji izvedle različne študije, da bi vzpostavile pravno-upravni okvir urbanističnega oblikovanja in pripravile oblikovalske smernice za ohranjanje identitete zgodovinskih mest pod pritiski hitre urbanizacije. V članku sta avtorici pojasnili, kako sta $\mathrm{v}$ praksi izvedli model participativne priprave oblikovalskih smernic za območja kulturne dediščine, ki sta ga oblikovali v okviru znanstvenoraziskovalnega projekta. Predstavili sta uporabo raznih metod, da se lahko v pripravo oblikovalskih smernic za območja kulturne dediščine vključi raznovrstne akterje, razpravljali sta o pomembnosti metod in procesov vključevanja lokalne skupnosti v pripravo teh smernic, na podlagi primerov iz Združenega kraljestva in Turčije pa sta osvetlili področje uporabe smernic za trajnostno ohranjanje območij kulturne dediščine na splošno. Predstavili sta še študijo primera, opravljeno v turškem mestu
Bursa, natančneje v predelu Hanlar, ki je na Unescovem seznamu svetovne dediščine. Študija je obsegala raziskavo načrtovalskih odločitev, analizo območja, anketo med mestnimi prebivalci, poglobljene intervjuje z lokalnimi obrtniki in oblikovalsko delavnico $\mathrm{z}$ raznovrstnimi akterji. V predstavitvi glavnih izsledkov študije so med drugim navedeni uporaba raznih načinov vključevanja skupnosti v pripravo oblikovalskih smernic za območja kulturne dediščine v Turčiji, sistem oblikovalskih usmeritev za Burso in seznam priporočil, povezanih z oblikovalskimi smernicami za Hanlar in Burso, sestavljen na podlagi primerov iz Združenega kraljestva.

Ključne besede: oblikovalske smernice, kulturna dediščina, vključenost skupnosti, območja Unescove svetovne dediščine, Hanlar 


\section{Uvod}

Območja kulturne dediščine, ki imajo številne družbenokulturne in družbenogospodarske vrednote, ki lokalnim skupnostim omogočajo, da se povežejo s svojo preteklostjo, so izjemnega pomena za ohranjanje mestne identitete in spomina. Hitra urbanizacija kot posledica rasti prebivalstva, mestne prenove, čedalje večjega prometa ali turističnih pritiskov - težav, $s$ katerimi se trenutno spoprijemajo mnoga mesta - negativno vpliva na pristnost in celovitost območij kulturne dediščine v mestnih središčih (Hassler idr., 2002; ICOMOS, 2005; Van Oers, 2010; Aksoy in Enlil, 2012; Brombach idr., 2013). Poleg tega pomanjkanje celovitega sistema trajnostnega načrtovanja, ohranjanja in oblikovanja, zlasti pomanjkanje osnovnih orodij za vključevanje lokalne skupnosti in urbanistično oblikovanje, ogroža trajnostni razvoj območij kulturne dediščine v državah v razvoju, saj se $s$ tem slabša kakovost javnega življenja in prostora.

Danes se raziskave s področja kulturne dediščine osredotočajo na strategije trajnostnega ohranjanja in razvoja območij, pri katerih imajo pomembno vlogo orodja za vključevanje skupnosti in urbanistično oblikovanje (Özcan, 2009). Za ohranjanje enotnosti, kontinuitete in pristnosti območij kulturne dedišcine je treba pripraviti in izvajati zakonske ali neformalne (zakonsko neobvezujoče) oblikovalske smernice (Tiesdell idr., 1996). Smernice za urbanistično oblikovanje večinoma obsegajo dopolnilne planske dokumente, ki zagotavljajo dodatne informacije in nasvete pri zadevah $s$ področja urbanističnega oblikovanja. Pojasnjujejo, kako se lahko posamezna vrsta gradnje izvaja v skladu z oblikovalskimi načeli načrta. Smernice predstavijo niz oblikovalskih načel, ki veljajo za izbrani projekt, opredelijo običajne oblikovalske napake in izvajalcu pomagajo, da se jim izogne, ter lokalnim oblastem olajšajo sporazumevanje in pogajanje $\mathrm{z}$ vsemi deležniki, vključenimi v gradnjo (DETR, 2000). Zlasti na območjih kulturne dediščine centralna vlada in lokalne uprave mestno gradnjo izvajajo ob upoštevanju oblikovalskih smernic za ohranjanje lokalnih značilnosti (Madanipour, 1996; DETR in CABE, 2000). Smernice je treba pripraviti ob upoštevanju značilnosti posameznega mesta, mestnega predela ali območja kulturne dediščine (Von Hausen, 2013). Pri tem je zelo pomembna vključenost lokalne skupnosti, saj je ta ključna za okrepitev njene vloge, izboljšanje oblikovalskih predlogov na zgodovinskih območjih, doseganje soglasja med akterji, da se zahteve za izdajo gradbenega dovoljenja lahko obdelujejo tekoče in hitreje, ter za ustvarjanje občutka pripadnosti in krepitev družbenih vezi v njenem okviru (Yeang, 2000).

Številne raziskave poudarjajo pomen vključenosti skupnosti v študije s področja urbanističnega oblikovanja, da bi se trajnostno ohranjala območja kulturne dedišcine $\mathrm{v}$ mestih. Carmona (2009) na primer navaja, da je eno izmed deset splošnih oblikovalskih načel tudi samozadostnost, ki zahteva vključenost lokalne skupnosti v urbanistično oblikovanje. Nasser (2003) poudarja, da sta ponovna združitev urbanih oblik $\mathrm{z}$ dejavnostmi in rabami, ki potekajo $\mathrm{v}$ mestu, ter povezovanje načrtovanja rabe zemljišč $s$ potrebami in željami lokalnih prebivalcev ključna za celostni razvoj skupnosti na območjih kulturne dediščine. Elnokaly in Elseragy (2013) pojasnjujeta, da je treba za trajnostno ohranjanje mestnih območij ohranjati značilno mestno tkivo ter poglavitne lastnosti zgodovinskih območij in življenja skupnosti, ki tam živijo, hkrati pa dejanske strukture in dejavnosti prilagajati sodobnim zahtevam. Tudi Križnik (2018) poudarja potrebo po sodelovanju javnosti, saj to zagotavlja družbeno kohezijo ter omogoča trajnostno urbano regeneracijo in prenovo degradiranih mestnih območij.

Avtorici članka sta razložili, kako sta izvedli model participativne priprave oblikovalskih smernic, ki sta ga oblikovali v okviru znanstvenoraziskovalnega projekta v Hanlarju - enem izmed območij pod Unescovo zaščito v turški Bursi. Postavili sta te hipoteze:

- orodja za urbanistično oblikovanje imajo $\mathrm{v}$ državah $\mathrm{v}$ razvoju pomembno vlogo pri trajnostnem ohranjanju območij kulturne dediščine;

- vključevanje lokalne skupnosti je v državah v razvoju sestavni del urbanističnega načrtovanja in oblikovanja;

- za ohranjanje predela Hanlar v Bursi so potrebne raznovrstne oblikovalske smernice.

V okviru raziskave, predstavljene v članku, sta bila poleg tega izvedena ukrepa, opredeljena v upravljavskem načrtu za Burso in Cumalıkızık. Prvi se nanaša na pripravo oblikovalskih smernic, ki ustrezajo značilnostim posameznega upravljavskega območja in s tem omogočajo ohranitev lokalnih značilnosti v skladu z načeli urbanističnega oblikovanja. Drugi ukrep pa se nanaša na uravnoteženje kulturnih vrednot in družbenogospodarskega položaja območja z zagotavljanjem aktivnega vključevanja in sodelovanja javnosti, da se izboljša kakovost življenja (Bursa Site Management Unit, 2013).

\section{Izkušnje iz Združenega kraljestva: orodja za urbanistično oblikovanje in vključevanje lokalne skupnosti na območjih kulturne dediščine}

Upravljavska orodja na področju urbanističnega oblikovanja se delijo na formalna (zakonsko predpisana) in neformalna (zakonsko neobvezujoča). Formalna orodja se delijo še na usmerjanje, spodbujanje in nadzor, $\mathrm{z}$ vidika dela komisije iz Združe- 
Preglednica 1: Proces in metode vključevanja lokalne skupnosti v pripravo oblikovalskih orodij - primeri iz Združenega kraljestva

\begin{tabular}{|c|c|c|c|}
\hline Orodje & Status & Metode posvetovanja in vključevanja & $\begin{array}{l}\text { Orodja za vključevanje skupnosti in posveto- } \\
\text { vanje }\end{array}$ \\
\hline $\begin{array}{l}\text { Dopolnilni planski } \\
\text { dokumenti } \\
\text { v Liverpoolu }\end{array}$ & $\begin{array}{l}\text { Niso del občinskega } \\
\text { prostorskega načrta. } \\
\text { Prosilcem pomagajo, } \\
\text { da so njihove vloge } \\
\text { uspešne. }\end{array}$ & $\begin{array}{l}\text { Obveščanje zakonsko določenih svetoval- } \\
\text { cev po navadni ali e-pošti, objava doku- } \\
\text { mentov na spletni strani liverpoolskega } \\
\text { mestnega sveta, kjer javnost lahko poda } \\
\text { mnenja, izjave za javnost in javna obvestila, } \\
\text { razpošiljanje elektronskega gradiva prek } \\
\text { krovnih organizacij, namenski sestanki. }\end{array}$ & $\begin{array}{l}\text { Izjava o vključevanju lokalne skupnosti v Liver- } \\
\text { poolu: štiritedensko posvetovanje. } \\
\text { - neformalna javna razprava } \\
\text { - objava osnutka dopolnilnega planskega } \\
\text { dokumenta (SPD) za morebitne pripombe } \\
\text { - sprejetje SPD }\end{array}$ \\
\hline $\begin{array}{l}\text { Dopolnilni planski } \\
\text { dokumenti v Bathu }\end{array}$ & $\begin{array}{l}\text { Dopolnjujejo politi- } \\
\text { ko, predstavljeno v } \\
\text { prostorskorazvojnih } \\
\text { dokumentih (DPD), } \\
\text { sprejeti morajo biti v } \\
\text { skladu z zakonsko do- } \\
\text { ločenim postopkom } \\
\text { in niso podvrženi for- } \\
\text { malnemu pregledu. }\end{array}$ & $\begin{array}{l}\text { Mediji, obveščanje po navadni ali e-pošti, } \\
\text { obveščanje na izbranem območju, lokalni } \\
\text { časopisi/reklame, internet, telefonska linija } \\
\text { za pomoč, seminarji in predavanja, javni } \\
\text { vpogled, formalni in neformalni dialog, } \\
\text { sestanki in interaktivne delavnice, ankete, } \\
\text { usmerjevalne, svetovalne in delovne sku- } \\
\text { pine, razprave s posamezniki in skupinami, } \\
\text { notranje razprave v podjetjih. }\end{array}$ & $\begin{array}{l}\text { Izjava o vključevanju lokalne skupnosti v uprav- } \\
\text { ni enoti Bath and North East Somerset: šestte- } \\
\text { densko formalno posvetovanje. } \\
\text { - neformalno vključevanje skupnosti v pri- } \\
\text { pravo osnutka SPD } \\
\text { - formalno posvetovanje o SPD } \\
\text { - lokalni svet sprejme SPD }\end{array}$ \\
\hline
\end{tabular}

\begin{tabular}{|c|c|c|c|}
\hline \multirow[t]{7}{*}{$\begin{array}{l}\text { Dopolnilne usmeri- } \\
\text { tve in načrtovalske } \\
\text { smernice v Edin- } \\
\text { burgu }\end{array}$} & \multirow[t]{7}{*}{$\begin{array}{l}\text { Povezane so s strate- } \\
\text { škimi ali občinskimi } \\
\text { prostorskimi načrti. } \\
\text { Dopolnilne usmeritve } \\
\text { so del prostorskega } \\
\text { načrta. }\end{array}$} & \multirow[t]{7}{*}{$\begin{array}{l}\text { Vprašalnik in analiza v aplikaciji Survey } \\
\text { Monkey, pisni odgovori organizacij in posa- } \\
\text { meznikov, blog o oblikovalskih smernicah, } \\
\text { brošure za javnost in deležnike, oglasi na } \\
\text { avtobusnih postajališčih, delavnice, predsta- } \\
\text { vitev in povratne informacije na omizjih. }\end{array}$} & $\begin{array}{l}\text { Nasveti glede prostorskega urejanja (ang. plan- } \\
\text { ning advice note): vključevanje lokalne skupno- } \\
\text { sti: obravnava v medijih, štiritedensko posve- } \\
\text { tovanje. } \\
\text { - uporaba programa VOiCE za vzpostavitev } \\
\text { in izvedbo učinkovitega vključevanja }\end{array}$ \\
\hline & & & $\begin{array}{l}\text { Poročilo o posvetovanju glede smernic za obli- } \\
\text { kovanje ulic v Edinburgu }\end{array}$ \\
\hline & & & - določitev obsega pregleda \\
\hline & & & • ozaveščanje ali preverjanje ozaveščenosti \\
\hline & & & - razpošiljanje osnutka za posvetovanje \\
\hline & & & - ozaveščanje in ocene \\
\hline & & & - preizkus smernic v praksi \\
\hline
\end{tabular}

Vir: LCC (2013); BNESC (2007); CEC (2018c); The Scottish Government (2010).

nega kraljestva za arhitekturo in grajeno okolje (ang. Commission for Architecture and the Built Environment ali CABE) pa neformalna orodja obsegajo vse od zbiranja primerov, širjenja znanja, aktivnega spodbujanja oblikovanja in ocenjevanja oblikovalske kakovosti do neposredne pomoči pri oblikovalskih projektih in/ali procesih (Carmona, 2017). Oblikovalske smernice bi lahko opisali kot usmeritve, kako doseči oblikovalske cilje (Lang, 1996) na podlagi oblikovalskih izhodišč, kot so usklajenost $s$ prostorskim kontekstom, usklajenost z merilom, ravnovesje med javnim in zasebnim prostorom ter prostorska kakovost, dostopnost in pretočnost, usklajenost gostote pozidave $\mathrm{z}$ vrsto rabe, mešana raba in tipologija stavb ter trajnostna gradnja in okolje. V skladu s temi izhodišči je treba doseči tudi cilje urbanističnega oblikovanja, kot so ohranitev narave, kontinuiteta in ograjenost, kakovost javnega prostora, dostopnost, berljivost, prilagodljivost in skladnost, raznovrstnost in ekološko ravnovesje (DETR in CABE, 2000; Yeang, 2000; Punter, 2007; Von Hausen, 2013).
Oblikovalskih smernic, ki temeljijo na ciljih urbanističnega oblikovanja, je več vrst. Carmona (2011) opredeljuje štiri vrste formalnih oblikovalskih smernic z različno stopnjo lokacijske specifičnosti in interpretacije: standardi (splošni, predpisovalni), predpisi (veljajo za zadevno območje, predpisovalni), usmeritve (splošne, ciljne) in okviri (veljajo za zadevno območje, ciljni). Poleg teh se v Združenem kraljestvu pogosto uporabljajo tudi neformalne smernice, ki se nanašajo na splošne vidike oblikovalske ali urbanistične prakse in so namenjene izmenjavi primerov dobre prakse $\mathrm{z}$ vidika oblikovalskega procesa ali izsledkov (Cowan, 2002; CABE, 2003; Ministry of Environment and Urbanization in Mimar Sinan Fine Arts University, 2016; Carmona, 2017).

V načrtovalski praksi v Združenem kraljestvu se uporabljajo različne kategorije smernic in orodij. Oblikovalske smernice vsebujejo nasvete o ključnih oblikovalskih točkah, ki jih je treba upoštevati pri določanju načrtovalskih procesov in orodij. 
Poleg tega politične izjave in zakoni v Združenem kraljestvu spodbujajo vključevanje lokalne skupnosti v zadeve s področja urbanističnega oblikovanja, upravljanja območij kulturne dediščine in urejanja prostora. Lokalne oblasti v Združenem kraljestvu izdajajo posebne izjave, s katerimi se lokalne skupnosti vključijo v oblikovanje prostorske politike in obravnavo zahtev za izdajo gradbenega dovoljenja (Royal Town Planning Institute in Consultation Institute, 2005).

V Liverpoolu in Bathu je vključenost lokalne skupnosti zagotovljena na podlagi izjav o vključevanju lokalne skupnosti, v katerih so pojasnjeni postopek, metode in druge podrobnosti vključevanja skupnosti v pripravo lokalnega prostorskorazvojnega okvira, vključno $s$ prostorskorazvojnimi dokumenti (ang. development plan documents, v nadaljevanju: DPD) in dopolnilnimi planskimi dokumenti (ang. supplementary planning documents, v nadaljevanju: SPD), ter v obravnavo zahtev za izdajo gradbenega dovoljenja (BNESC, 2007; LCC, 2013). SPD vsebujejo dodatne podatke o tem, kako naj bi se izvajale politike, določene v prostorskorazvojnih dokumentih. Mednje spadajo oblikovalske smernice, gradbeni napotki in tematske razprave. Vključenost skupnosti v pripravo SPD poteka predvsem v naslednjih treh fazah: neformalna javna razprava, formalno posvetovanje o osnutku SPD ter priprava in sprejetje končnega SPD. Za posvetovanje in vključevanje skupnosti se uporabljajo različne metode (preglednica 1; BNESC, 2007; LCC, 2013). V Liverpoolu so SPD - ki morajo biti v skladu z državno, regionalno in lokalno prostorsko politiko - uradno del prostorskorazvojnega okvira izbranega območja. Eden izmed takšnih dokumentov je tudi SPD o liverpoolskem obrežju, ki je na Unescovem seznamu svetovne dediščine (ang. Liverpool Maritime Mercantile City World Heritage Site SPD). Njegov cilj je zvišati standarde urbanističnega oblikovanja in ohranjanja kulturne dediščine ter predstaviti smernice za zaščito in povečanje izjemne univerzalne vrednosti območja svetovne kulturne dediščine, hkrati pa spodbuditi naložbe in gradnjo, ki zagotavljajo zdrav gospodarski razvoj za vse deležnike in podpirajo trajnostno regeneracijo (LCC, 2009). Tudi v Bathu veljajo različni SPD, ki jih je lokalni svet sprejel s posebnim sklepom in imajo pomembno vlogo pri sprejemanju načrtovalskih odločitev (BNESC, 2018). SPD, ki ocenjuje splošno podobo mesta Bath (ang. Bath City-Wide Character Appraisal $S P D)$, na primer opredeljuje ključne prvine mestne podobe, pri čemer izpostavlja razlike po mestu (BNESC, 2005). SPD o Bathu kot območju, ki spada v Unescovo svetovno dedišcino (ang. City of Bath WHS Setting SPD), zagotavlja podatke in orodja za učinkovito zaščito in ustrezno upravljanje zavarovanega območja (BNESC, 2013). Priročnik o urejanju ulične krajine (ang. Streetscape Manual SPD) je namenjen usmerjanju izbora, oblikovanja, urejanja in vzdrževanja ulične krajine in njenega ohranjanja (BNESC, 2005). Poleg naštetih dokumentov se uporablja tudi publikacija Pattern Book (v dveh delih), ki določa kakovost ulic in javnih prostorov v središču mesta (BNESC, 2015).

Na Škotskem se poleg zakonodaje uporabljajo tudi posebni nasveti glede prostorskega urejanja in usmeritve, ki se nanašajo na vključevanje skupnosti in so na voljo iz številnih virov (Royal Town Planning Institute in Consultation Institute, 2005). Če je treba v okviru prostorskega načrta oblikovati dopolnilne usmeritve, je treba po zakonu obvezno izvesti javno posvetovanje (The Scottish Government, 2010). V Edinburgu se uporabljata dve vrsti usmeritev. Dopolnilne usmeritve zagotavljajo dodatne informacije o politikah, sprejetih v edinburškem občinskem prostorskem načrtu, načrtovalske smernice pa dajejo nasvete o najrazličnejših temah, povezanih z novogradnjo (CEC, 2018a). Edinburški standardi urbanističnega oblikovanja (ang. Edinburgh Standards for Urban Design SG) na primer vsebujejo oblikovalska načela, ki se delijo na mestno, lokalno, območno/ulično in javno raven (CEC, 2003). V edinburških oblikovalskih usmeritvah (ang. Edinburgh Design Guidance $P G$ ) so predstavljena pričakovanja mestnega sveta v zvezi z oblikovanjem novogradenj v Edinburgu, ki morajo dosegati najvišjo oblikovalsko kakovost in se dobro ujemati s preostalim mestnim okoljem (CEC, 2018b). Edinburške usmeritve za oblikovanje ulic (ang. Edinburgh Street Design Guidance $S G$ ), katerih cilj je uskladiti obliko ulic in spodbuditi sodelovanje med strokami, so zakonsko neobvezujoč usmeritveni dokument, osredotočen na uporabnika (CEC, 2015). Usmeritve o spomeniško zaščitenih stavbah in zavarovanih območjih (ang. Guidance on Listed Buildings and Conservation Areas $P G)$ pa vsebujejo informacije o popravilu, spreminjanju ali razširitvi spomeniško zaščitenih in nezaščitenih stavb na zavarovanih območjih (CEC, 2019).

Anglija in Škotska sta torej dobra primera dežel, ki so oblikovale, opredelile in uporabile orodja za urbanistično oblikovanje in vključevanje skupnosti kot ključne prvine načrtovalske in oblikovalske zakonodaje ter strokovne prakse. V obeh so bile od državne do lokalne ravni za območja kulturne dediščine vzpostavljene različne vrste oblikovalskih orodij, ki podpirajo druga drugo. Orodja, sprejeta v okviru prostorskih načrtov, imajo formalni status dopolnilnega planskega dokumenta ali usmeritve, za katero se zahteva javno posvetovanje. Poleg teh so še usmeritve, ki pojasnjujejo, kako vključiti lokalno skupnost ter katera orodja je treba uporabiti pri načrtovanju, oblikovanju in ohranjanju območij (preglednica 1). V Združenem kraljestvu je tudi mnogo javnih organov, dobrodelnih organizacij in pobud, ki podpirajo in usmerjajo vključevanje lokalne skupnosti v državi.

Izkušnje iz Združenega kraljestva torej kažejo, da imajo orodja za urbanistično oblikovanje pomembno vlogo pri trajnostnem ohranjanju območij kulturne dediščine in da je vključenost 
lokalne skupnosti nepogrešljiv del načrtovalskega in oblikovalskega procesa v razvitih državah. $S$ tem sta potrjeni prva in druga hipoteza raziskave. Pregled orodij za urbanistično oblikovanje in vključevanje lokalne skupnosti v Združenem kraljestvu daje uporabne podatke za vključevanje lokalne skupnosti v pripravo oblikovalskih smernic in oblikovanje sistema oblikovalskih usmeritev v Bursi.

\section{Smernice za vključevanje lokalne skupnosti in urbanistično oblikovanje v turškem načrtovalskem sistemu}

Načrtovalski sistem v Turčiji je urejen z gradbenim zakonom št. 3194 iz leta 1985. Zakon in predpisi, ki iz njega izhajajo, pa nikjer ne opredeljujejo vključenosti lokalne skupnosti in urbanističnega oblikovanja $\mathrm{v}$ načrtovalskem sistemu. $\mathrm{V}$ okviru devetega razvojnega načrta sta bila leta 2010 oblikovana celostna urbanistična strategija in akcijski načrt (KENTGES), katerih cilj je bil izboljšati življenjski standard ter okrepiti gospodarsko, socialno in kulturno zgradbo mest. $V$ teh dokumentih je bila prvič opredeljena potreba po smernicah za urbanistično oblikovanje in vključenost skupnosti v turškem načrtovalskem sistemu. Po ustanovitvi oddelka za urbanistično oblikovanje pri generalnem direktoratu za prostorsko načrtovanje ministrstva za okolje in urbanizacijo leta 2013 se je povečalo število raziskav za razvoj prakse vključevanja skupnosti in pripravo oblikovalskih smernic (MPWS, 2010).

Leta 2014 je bil gradbeni zakon št. 3194 spremenjen, načela urbanističnega oblikovanja pa so bila opredeljena v uredbi o pripravi prostorskih načrtov. Poleg tega so novi predpisi določali, da je treba pripraviti oblikovalske smernice za oblikovanje mestne podobe in identitete, za povečanje estetske in umetniške vrednosti prostorov ter za usklajeno razvrščanje stavb na podlagi oblikovalskih projektov. Kljub temu je raziskava, ki sta jo opravili Rezafarjeva in Turkova (2018), pokazala, da številni dejavniki, povezani z urbanističnim oblikovanjem in estetsko presojo, niso vključeni $\mathrm{v}$ gradbeni zakon in preostalo turško prostorsko zakonodajo. Zato sta avtorici opredelili parametre, ki bi jih lahko vključili v zakonodajo na državni, mestni in lokalni ravni, vključno z oblikovalskimi smernicami.

Omenjena uredba neposredno ne omenja vključenosti skupnosti v načrtovalski proces, vendar poudarja, da morajo biti sprejeti okoljski in občinski prostorski načrti javno objavljeni za morebitne pripombe, ki se lahko predložijo v 30 dneh, vse vrste načrtov in njihove priloge morajo biti dostopni javnosti, medijem in elektronskim komunikacijam, javnost pa se lahko o načrtih obvešča na seminarjih, konferencah, razstavah in drugih srečanjih. Navodila za pripravo in oceno oblikovalskih projektov, ki jih mora odobriti ministrstvo za okolje in urbanizacijo (Ministry of Environment and Urbanisation, 2015), poleg tega določajo, da je eden izmed ciljev projektov urbanističnega oblikovanja olajšati javna pogajanja na podlagi obveščanja prebivalcev, strokovnih zbornic in nevladnih organizacij o oblikovalskih projektih na sestankih z lokalnimi vodji, tiskovnih konferencah ipd. ter pripraviti poročila o njihovih mnenjih in priporočilih. $V$ navodilih pa ni opredeljena nobena metoda vključevanja skupnosti, ki bi pospešila javna pogajanja. Trenutno na ministrstvu v sodelovanju s strokovnimi zbornicami, univerzami in nevladnimi organizacijami potekajo študije, povezane z oblikovanjem prakse vključevanja skupnosti in pripravo oblikovalskih smernic, $\mathrm{v}$ bližnji prihodnosti pa bo ministrstvo od občin zahtevalo, da oblikovalske smernice tudi dejansko pripravijo.

Raziskave izvajajo različne javne ustanove, avtorici pa sta ugotovili, da vlada vrzel pri raziskavah $s$ področja trajnostnega ohranjanja mestnih območij kulturne dediščine z vidika uporabe orodij za urbanistično oblikovanje. Zato sta leta 2012 na univerzi Uludag v Bursi začeli izvajati raziskovalni projekt o modelu smernic za urbanistično oblikovanje v mestnem središču Burse, katerega cilj je razviti model participativne priprave oblikovalskih smernic za območja kulturne dediščine. V okviru projekta sta med letoma 2012 in 2015 izvedli tudi študijo primera v predelu Hanlar v Bursi.

\section{Gradivo in metode}

Bursa (slika 1) je četrto največje turško mesto, je na jugu pokrajine Marmara, v njem pa je leta 2017 živelo 2,936.803 ljudi. On nekdaj je veljalo za pomembno civilizacijsko središče, njegovi začetki pa segajo v leto 6500 pr. n. št. Mesto Prusa (danes Bursa) so leta 185 pr. n. št. ustanovili Bitinijci. Mesto je bilo nato pod rimsko in bizantinsko oblastjo, nato pa ga je leta 1326 osvojil sultan Orhan in ga spremenil v prestolnico Otomaskega cesarstva (Bursa Site Management Unit, 2013).

Bursa in bližnja vas Cumalıkızık sta bili leta 2014 na podlagi štirih meril nominirani za vpis na Unescov seznam svetovne kulturne dediščine (Bursa Site Management Unit, 2013). Šlo je za serijsko nominacijo osmih območij (na šestih vplivnih območjih; slika 1), ki ponazarjajo nastanek mestnega in podeželskega sistema Otomanskega cesarstva (Bursa Site Management Unit , 2013). Hanlar (slika 1) je eno izmed območij kulturne dediščine v središču Burse. Nastalo je v 14. stoletju kot trgovsko središče ob karavanskih poteh ob vznožju gore Uludag, v njem pa je mnogo primerkov monumentalne in civilne arhitekture (npr. gostišča, mošeje, javna kopališča in bazarji), ki so vse do danes ohranili svojo celovitost in avtentičnost (npr. kompleks Orhana Ghazija). Predel ponazarja mestno identiteto Burse z njenimi izvornimi urbanističnimi in arhitekturnimi značilnostmi ter tradicionalno trgovsko dejavnostjo. 


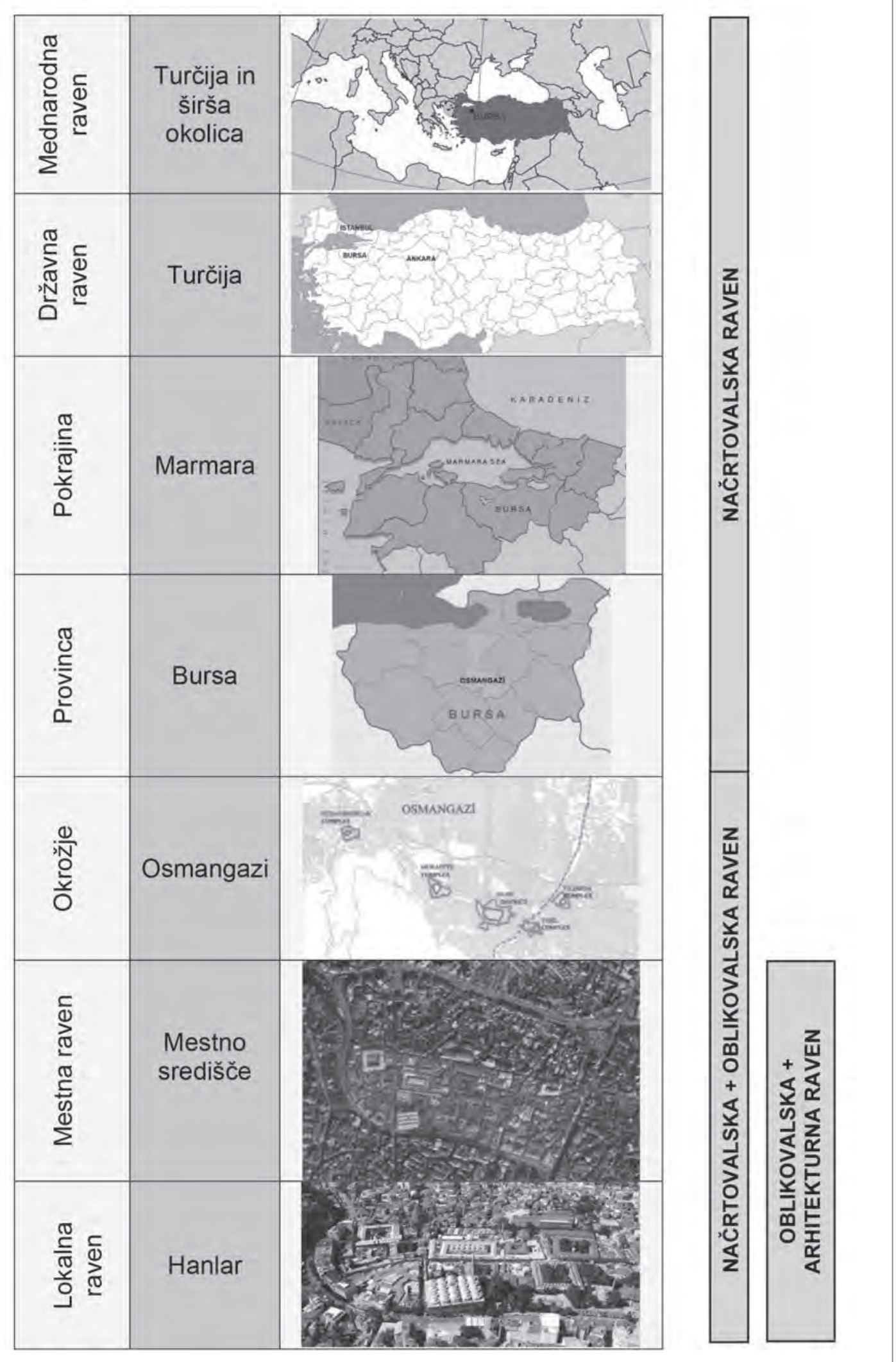

Slika 1: Lokacija proučevanega območja na različnih načrtovalskih ravneh (vir: Bursa Site Management Unit, 2013; ilustracija: avtorici) 


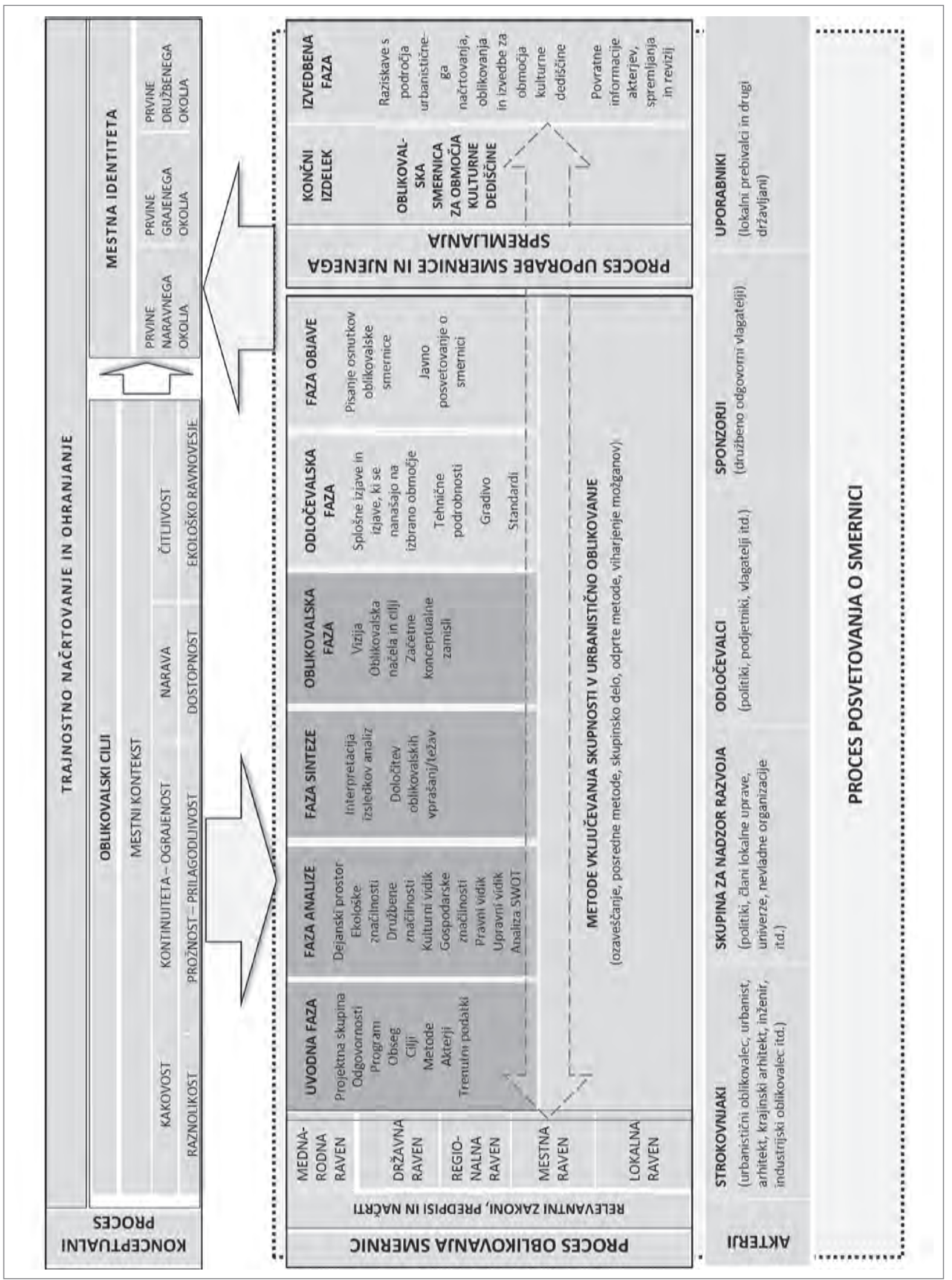

Slika 2: Model participativne priprave oblikovalskih smernic za območja kulturne dediščine (vir: Polat idr., 2018) 


\subsection{Raziskovalna metodologija}

Ta raziskava je del raziskovalnega projekta, katerega namen je bil razviti model participativne priprave oblikovalskih smernic za središče Burse. V članku se avtorici nista osredotočili na to, kako je projektna ekipa razvila model, ampak sta predstavili načine vključevanja lokalne skupnosti v pripravo oblikovalskih smernic za Hanlar na podlagi prakse v Združenem kraljestvu. $\mathrm{V}$ članku je predstavljen tudi model (slika 2) z vsemi fazami raziskave.

Metodologija raziskave je razdeljena $\mathrm{v}$ tri faze. $\mathrm{V}$ fazi analize sta avtorici proučili prostorske in upravljavske načrte in oblikovalske smernice, ki trenutno veljajo za Hanlar, ter opravili terensko analizo območja, anketo med prebivalci (uporabniki) in poglobljene intervjuje z lokalnimi obrtniki ob upoštevanju oblikovalskih vprašanj in ciljev upravljavskega načrta za Burso in Cumalıkızı. V fazi sinteze sta ovrednotili izsledke analiz in razvrstili zaznane težave s področja urbanističnega oblikovanja in pričakovanja uporabnikov in lokalnih obrtnikov v posamezne kategorije. V oblikovalski fazi sta oblikovali priporočila za urbanistično oblikovanje, na podlagi katerih bi se rešile težave in izpolnila pričakovanja prebivalcev, organizirana pa je bila tudi participativna oblikovalska delavnica, na kateri so študenti arhitekture razvili oblikovalske projekte za neizkoriščene javne prostore v Hanlarju. Na tej podlagi je lahko projektna skupina nato razvila model participativne priprave oblikovalskih smernic za območja kulturne dediščine (slika 3).
Model vključuje štiri osnovne procese (konceptualizacijo, oblikovanje smernic, spremljanje njihove uporabe in posvetovanje o njih) za oblikovanje in izvedbo smernice za urbanistično oblikovanje. Konceptualizacija temelji na vprašanjih urbanističnega oblikovanja in prvinah mestne identitete $\mathrm{z}$ vidika trajnostnega ohranjanja mestnih območij. Oblikovanje smernic temelji na urbanističnem oblikovanju in se deli v šest med seboj povezanih korakov ali faz (tj. na uvodno, analitično, sintetično, oblikovalsko in odločevalsko fazo ter fazo objave). Spremljanje uporabe smernic pomeni, da se bodo med uporabo izdelane smernice proučevale prejete povratne informacije in se bodo izvajale revizije. Posvetovanje o smernici pa temelji na določanju akterjev in metod vključevanja skupnosti v urbanistično oblikovanje ter se izvaja skupaj s preostalimi tremi procesi (s konceptualizacijo, oblikovanjem in spremljanjem uporabe smernic). Vsi navedeni procesi so med seboj povezani, prožni in se lahko prilagodijo glede na prejete povratne informacije (Polat idr., 2018).

\subsection{Ovrednotenje sprejetih načrtovalskih odločitev}

Območje Reyhan-Kayhan-Hanlar je bilo zaradi svojega zgodovinskega pomena leta 1986 razglašeno za območje mestne kulturne dediščine. Zanj, vključno s predelom Hanlar, so bili sprejeti strateški, glavni in občinski prostorski načrt. Glavni cilj okoljskega načrta iz leta 1998 za Burso, z veljavnostjo do leta 2020 in izdelanega v merilu $1: 100.000$, je bil ohranitev,

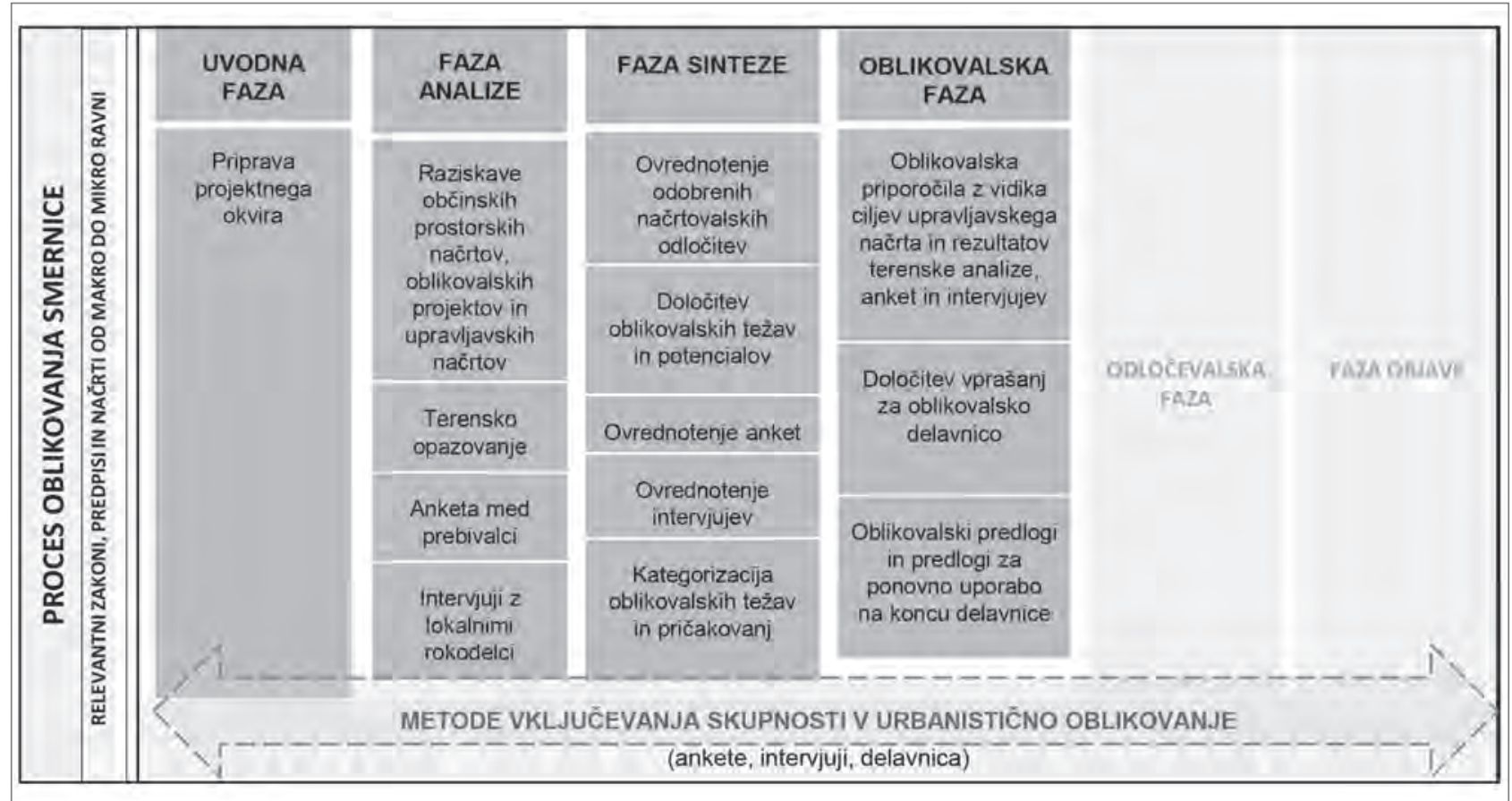

Slika 3: Izvedba modela participativne priprave oblikovalskih smernic v Hanlarju (ilustracija: avtorici) 
obnova in sanacija starega mestnega jedra na osrednjem ureditvenem območju ter spodbujanje rasti storitvenega sektorja na tem območju do leta 2020. Gostota pozidave se ni smela povečati. V načrtu ohranitve osrednjega območja Burse in območja Reyhan-Kayhan-Hanlar (merilo: 1 : 1.000; 1988 - 2005) je bilo določenih sedem posebnih projektnih območij v Hanlarju, na katerih lahko kakršna koli oblika gradnje (npr. obnove, popravila in rekonstrukcije) poteka samo v okviru projektov obnove, spremembe namembnosti objektov in urbanističnega oblikovanja, ki jih predhodno odobri odbor za ohranjanje kulturne in naravne dediščine v Bursi. Kljub temu do zdaj še niso bili razviti oblikovalski projekti ali orodja za območje Hanlarja. Čeprav je bil leta 2012 organiziran oblikovalski natečaj za trg Orhangazi in njegovo okolico v Hanlarju, projekt, ki je na tem natečaju zmagal, še ni bil izveden.

Ob ustanovitvi enote za upravljanje območij kulturne dediščine v Bursi je bila vložena nominacija za vpis Burse na Unescov seznam svetovne kulturne dediščine. Leta 2013 je bil tako na participativni podlagi pripravljen upravljavski načrt za Burso in Cumalıkızı, ki določa cilje in ukrepe, povezane s težavami, s katerimi se spoprijemajo območja kulturne dediščine. Glavne težave v Hanlarju so pomanjkanje celostnega pristopa $\mathrm{k}$ upravljanju območja, pomanjkanje skupne podatkovne zbirke za izmenjavo podatkov med ustanovami, stari in neustrezni lokalni konservatorski načrti, dejansko in funkcionalno propadanje objektov, majhna raznolikost uporabnikov, arhitekturno neskladje med novo zgrajenimi objekti in zgodovinsko grajeno strukturo ter preveč nezakonitih prizidkov $\mathrm{k}$ zgodovinskim stavbam, ki zasenčijo njihovo izvirno arhitekturno podobo. Te težave lahko razdelimo v naslednjih pet kategorij oblikovalskih vprašanj: upravljanje in vključevanje ( $\mathrm{v}$ procesu urbanističnega oblikovanja), dostopnost in pretočnost, usklajenost z merilom, trajnostna gradnja in okolje ter usklajenost mešane rabe. Predlagane oblikovalske smernice bi torej morale reševati našteta oblikovalska vprašanja in $s$ tem zagotoviti trajnostni razvoj Hanlarja.

\subsection{Izsledki terenske analize}

Med terensko analizo je projektna skupina na ravni mesta in stavb odkrila podobne težave in potenciale, kot so opredeljeni $v$ upravljavskem načrtu. $V$ glavnem se nanašajo na pomanjkanje prostorske kakovosti in mešane rabe, težave $\mathrm{z}$ varnostjo ponoči, slab dostop za pešce in propadanje zgodovinske grajene strukture. Lahko jih razdelimo v naslednjih pet skupin oblikovalskih vprašanj: usklajenost $s$ prostorskim kontekstom, usklajenost $\mathrm{z}$ merilom, ravnovesje med javnim in zasebnim prostorom, prostorska kakovost, dostopnost in pretočnost ter ravnovesje med mešano rabo in tipologijo stavb. Območje ima tudi mnogo potencialov: zaradi svojega zgodovinskega in kulturnega pomena je na Unescovem seznamu svetovne dediščine, je lahko dosto- pno območje v mestnem središču, poleg tega ima več praznih parcel, ki bi se lahko pozidale. Da bi se zagotovila vključenost lokalne skupnosti, so bili v druge faze raziskave vključeni tudi lokalni prebivalci in obrtniki.

\subsection{Izsledki ankete}

V okviru raziskave je bila opravljena tudi anketa med mestnimi prebivalci. Njen glavni cilj je bil analizirati Hanlar z vidika osnovnih oblikovalskih vprašanj (tj. usklajenost s prostorskim kontekstom, usklajenost z merilom, ravnovesje med javnim in zasebnim prostorom, prostorska kakovost, dostopnost in pretočnost, usklajenost gostote pozidave $\mathrm{z}$ vrsto rabe, mešana raba in tipologija ter trajnostna gradnja in okolje). $S$ tem sta avtorici lahko določili glavna vprašanja, ki bi jih bilo treba upoštevati v predlagani oblikovalski smernici. Ciljna populacija ankete so bili obiskovalci nakupovalnih središč. Danes številni mestni prebivalci raje preživljajo čas $\mathrm{v}$ nakupovalnih centrih kot v mestnih središčih, zato so mnoga mestna središča zapuščena in propadajo. Anketa je bila zato oblikovana tako, da je ugotavljala mnenje, zadovoljstvo in pričakovanje obiskovalcev nakupovalnih središč v Hanlarju v povezavi s tem, kaj bi jih pritegnilo v mestno središče.

Anketa je bila opravljena $\mathrm{v}$ štirih največjih nakupovalnih središčih v Bursi, eno izmed katerih je prav tako kot predel Hanlar v središču mesta in je zato njegov največji tekmec $\mathrm{v}$ smislu pritegovanja obiskovalcev. Anketa je bila izvedena med 370 obiskovalci nakupovalnih središč. Obiskovalci, ki so v Bursi živeli manj kot leto, turisti in zaposleni v nakupovalnih središčih so bili iz nje izključeni. Anketni vprašalnik je vseboval 34 vprašanj, anketiranci pa so ga izpolnjevali od 10 do $12 \mathrm{mi}-$ nut. Prvi del vprašalnika se je nanašal na osebne značilnosti anketirancev, največja težava pa je bila premajhna raznolikost uporabnikov. Drugi del vprašalnika je temeljil na vprašanjih o najznačilnejših prvinah in podobi Hanlarja. Izsledki so pokazali, da je glavna težava pomanjkanje občutka pripadnosti skupnosti. Promet, hrup, kaos in gneča na tem območju negativno vplivajo na podobo kraja in družbeno interakcijo. Tretji del vprašalnika je vključeval vprašanja o navadah in težavah v Hanlarju ter njegovem upravljanju. Osnovne težave so gost promet, slab dostop do območja, malo obiskovalcev, pomanjkanje parkirišč, neizkoriščeni javni prostori v nekaterih restavracijah, slabo upravljanje in oglaševanje območja ter slaba obveščenost ljudi o nominaciji območja kulturne dedišcine. Zadnji, četrti del vprašalnika je vseboval vprašanja o pričakovanjih uporabnikov glede Hanlarja. Izsledki so pokazali, da vlada največja potreba po novih območjih za kulturne dejavnosti, spremembi namembnosti zgodovinskih stavb in novih oblikovalskih predlogih za neizkoriščene javne prostore na tem območju. Težave in pričakovanja, o katerih so poročali obiskovalci nakupovalnih središč, se osredotočajo na naslednjih pet 
oblikovalskih vprašanj: dostopnost in pretočnost, usklajenost z merilom, usklajenost mešane rabe, ravnovesje med javnim in zasebnim prostorom ter prostorska kakovost in usklajenost $s$ prostorskim kontekstom.

\subsection{Izsledki poglobljenih intervjujev}

Da bi ocenili družbenogospodarske razmere lokalnih prebivalcev, sta se avtorici odločili, da bosta opravili intervjuje s skupino lokalnih obrtnikov v Hanlarju. Avtorici sta opravili 22 poglobljenih intervjujev, in to v sodelovanju z združenjem zgodovinskega bazarja in območja Hanlar v Bursi (ang. Association of Bursa Historical Bazaar and Hanlar District, v nadaljevanju: BTCHBD), nevladno organizacijo, katere cilj je ohraniti zgodovinsko grajeno strukturo območja, zadovoljiti trenutne potrebe in zahteve družabnega življenja na območju in doseči, da postane privlačno za obiskovalce (BTCHBD, 2010). Uporabili sta polstrukturirano obliko intervjujev, ki so trajali približno 15 do 20 minut. Obrtniki z različnih področij so svoj poklic ocenili z vidika dohodka in vrste strank ter razkrili svoja pričakovanja v zvezi s fizičnoprostorskimi, gospodarskimi, družbenimi, kulturnimi in funkcionalnimi dejavniki proučevanega območja. Po mnenju intervjuvancev so glavne težave na tem območju naslednje:

- nezadostno sodelovanje med ustanovami in lokalnimi obrtniki (pomanjkanje ustreznih dovoljenj, slaba vključenost obrtnikov v odločanje, pomanjkanje priložnosti za promocijo območja, slabe izobraževalne možnosti za lokalne obrtnike itd.);

- ovirano izvajanje projektov obnove in spremembe namembnosti objektov zaradi visoke stopnje zasebnega lastništva;

- majhna raznolikost in malo strank (zaradi pomanjkanja območij z mešano rabo in težav z varnostjo, šibke kupne moči, majhne privlačnosti bazarja zaradi novih nakupovalnih središč v mestnih predelih, ki se širijo proti zaho$\mathrm{du}$, ter prevlade domačih turistov in turistov z Bližnjega vzhoda);

- slaba prometna infrastruktura in slab dostop (neustrezna mesta za prestopanje, pomanjkanje urejenih površin za pešce in parkirišč).

Izsledki so pokazali, da se težave in pričakovanja lokalnih obrtnikov osredotočajo na naslednjih pet oblikovalskih vprašanj: upravljanje in vključenost ( $v$ procesu urbanističnega oblikovanja), usklajenost mešane rabe, usklajenost $\mathrm{z}$ merilom, dostopnost in pretočnost ter trajnostna gradnja in okolje.

\subsection{Izsledki oblikovalske delavnice za središče Burse}

V skladu s cilji upravljavskega načrta in oblikovalskimi priporočili, oblikovanimi na podlagi anket in intervjujev, sta avtorici organizirali participativno oblikovalsko delavnico, katere namen je bil poiskati priložnosti za projekte urejanja javnega prostora $\mathrm{v}$ številnih predelih Hanlarja, podobne konceptualnim rešitvam v smernicah za Bath in Liverpool.

Delavnica se je osredotočala na projekte konceptualnega oblikovanja za neizkorǐ̌čene javne prostore v Hanlarju, pri čemer je bila vzpostavljena participativna platforma, ki je združevala številne akterje: predstavnike javnih ustanov, lokalnih oblasti, strokovnih zbornic, nevladnih organizacij in lokalnih prebivalcev, študente arhitekture in projektno skupino, ki je bila hkrati koordinator delavnice. Večina predlogov, ki so jih predstavili študenti, se je nanašala na spremembo namembnosti gostišč (tj. gostišča in javni prostori bi lahko postali prizorišča družabnih in kulturnih dogodkov, kar bi pripomoglo $\mathrm{k}$ ohranjanju tradicionalne kulture in značilnosti območja), drugi pa so se nanašali na ureditev novih zelenih površin in kakovostnih javnih prostorov v mestnem središču ter na vključevanje sodobnih arhitekturnih rešitev v zgodovinsko grajeno strukturo območja. Študenti so se pri oblikovanju predlogov osredotočali na reševanje naslednjih pet oblikovalskih vprašanj: usklajenost tipologije stavb $\mathrm{z}$ mešano rabo, usklajenost $s$ prostorskim kontekstom, ravnovesje med javnim in zasebnim prostorom, prostorska kakovost, dostopnost in pretočnost ter trajnostna gradnja in okolje. Delavnica je lokalnim voditeljem in drugim deležnikom omogočila, da so oblikovali novo vizijo za območja kulturne dediščine in hkrati izboljšali ozaveščenost mestnih prebivalcev o trajnostnem razvoju teh območij in uporabi orodij za vključevanje lokalne skupnosti.

\section{Razprava in priporočila}

$\mathrm{Z}$ vidika povezave med trajnostnim načrtovanjem, ohranjanjem območij, urbanističnim oblikovanjem in arhitekturo je raziskava pokazala, da so za območje Hanlarja v Bursi potrebne raznovrstne oblikovalske smernice. Zato je bil na podlagi primerov iz Združenega kraljestva za Burso predlagan sistem usmeritev za urbanistično oblikovanje, ki je potrdil tretjo hipotezo raziskave (slika 4). Metropolitanska občina Bursa bi morala oblikovalske smernice za Burso pripraviti v obliki formalnih dopolnilnih planskih dokumentov na podlagi participativnega pristopa. Sistem usmeritev je sestavljen iz treh ravni, opredeljenih v nadaljevanju. 


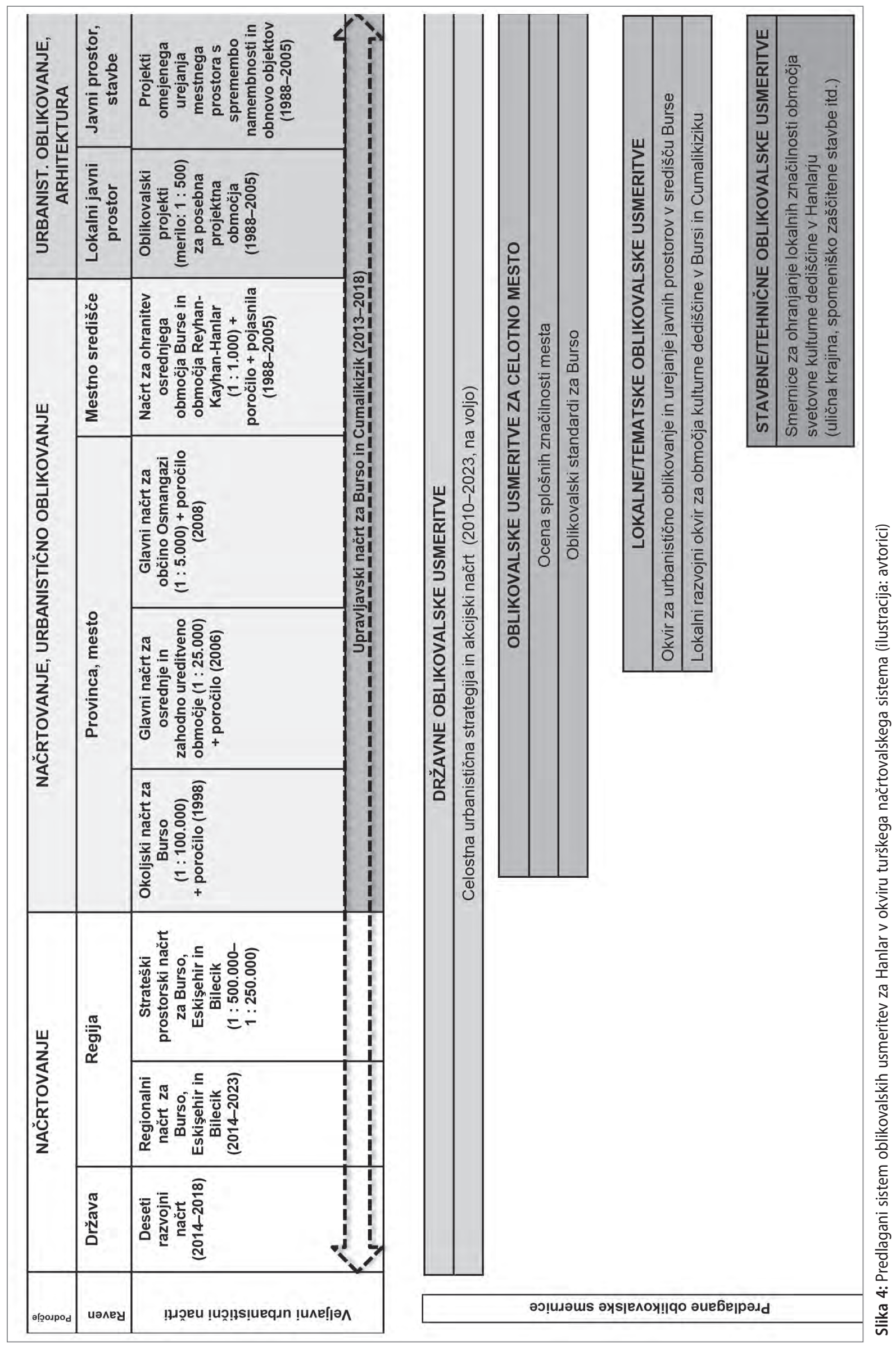


Preglednica 2: Napake pri reševanju oblikovalskih vprašanj v Hanlarju na podlagi izsledkov študije primera

\begin{tabular}{lllllll}
\hline & Analiza & & & & \\
Napaka pri reševanju oblikovalskih vprašanj & $\begin{array}{l}\text { Odločitve v načrtu } \\
\text { upravljanja } \\
\text { območja }\end{array}$ & $\begin{array}{l}\text { Terenska } \\
\text { analiza }\end{array}$ & Ankete & $\begin{array}{l}\text { Poglobljeni } \\
\text { intervjuji }\end{array}$ & Delavnica & Skupaj \\
\hline Usklajenost s prostorskim kontekstom & 2 & 5 & 3 & 1 & 4 & 15 \\
\hline Usklajenost z merilom & 4 & 5 & 5 & 4 & 3 & 21 \\
\hline $\begin{array}{l}\text { Ravnovesje med javnim in zasebnim } \\
\text { prostorom in prostorska kakovost }\end{array}$ & 2 & 4 & 4 & 2 & 4 & 16 \\
\hline Dostopnost in pretočnost & 5 & 4 & 5 & 4 & 4 & 22 \\
\hline Usklajenost gostote pozidave z vrsto rabe & 3 & 3 & 2 & 2 & 2 & 12 \\
\hline Usklajenost tipologije stavb z mešano rabo & 3 & 3 & 4 & 5 & 5 & 20 \\
\hline Trajnostna gradnja in okolje & 4 & 2 & 1 & 3 & 3 & 13 \\
\hline $\begin{array}{l}\text { Upravljanje in vključevanje (v procesu } \\
\text { oblikovanja) }\end{array}$ & 5 & 1 & 2 & 5 & 1 & 14 \\
\hline Opomba & & & & & 2 \\
\hline
\end{tabular}

Opomba: 1 (redko omenjeno) - 5 (pogosto omenjeno).

Oblikovalske usmeritve za celotno mesto:

- ocena splošnih značilnosti mesta bi morala dati vpogled $\mathrm{v}$ to, $\mathrm{v}$ čem se Bursa razlikuje od drugih mest;

- oblikovalski standardi za Burso bi morali opredeliti splošna oblikovalska načela za ohranjanje in izboljšanje vizualne podobe in identitete mesta ter zagotoviti visoko oblikovalsko kakovost novogradenj po vsem mestu.

Lokalne /tematske oblikovalske usmeritve:

- okvir za urbanistično oblikovanje in urejanje javnih prostorov v središču Burse bi moral biti izdelan v obliki prospekta, v katerem so predstavljene fizična oblika mestnega središča in možnosti njegove preobrazbe v naslednjih desetletjih;

- lokalni razvojni okvir za območja kulturne dediščine v Bursi in Cumalıkızıku bi moral vsebovati tematske smernice za zašcito in povečanje izjemne univerzalne vrednosti območij svetovne kulturne dediščine v Bursi, hkrati pa spodbuditi naložbe in gradnjo, ki zagotavljajo zdrav gospodarski razvoj in podpirajo trajnostno regeneracijo.

Stavbne /tehnične oblikovalske usmeritve:

- smernice za ohranjanje lokalnih značilnosti Hanlarja se lahko nanašajo na ulično krajino, spomeniško zaščitene stavbe, krajino, razsvetljavo, varnost pešcev in kolesarjenje.

Da bi bile smernice v praksi uporabne za Hanlar, bi morale upoštevati tudi pričakovanja lokalnih prebivalcev in obrtnikov. Na podlagi študije primera sta avtorici izdelali matriko napak pri reševanju oblikovalskih vprašanj in opravili pet analiz, da bi ugotovili, katere napake izstopajo v Hanlarju (preglednica 2).
Na podlagi teh izsledkov sta avtorici izdelali preglednico $s$ priporočili glede procesa in konteksta priprave oblikovalskih smernic za Hanlar ob upoštevanju pogledov mestnih prebivalcev (obiskovalcev nakupovalnih središč) in lokalnih obrtnikov ter primerov iz Združenega kraljestva (preglednica 3).

\section{Sklep}

Glavni prispevek raziskave, opisane v članku, je združitev številnih metod vključevanja lokalne skupnosti v pripravo oblikovalskih smernic. Če je skupnost v to vključena že od vsega začetka, lahko lokalne oblasti lažje rešujejo težave, ki se pojavijo pri pripravi oblikovalskih smernic. To so potrdili tudi primeri iz Združenega kraljestva. V raziskovalni vzorec so bili vključeni obiskovalci nakupovalnih središč in lokalni obrtniki. Lokalne skupnosti v Bursi so sestavljene iz različnih skupin. To so običajno težje dostopne skupine, kot so narodnostne manjšine, mladi, starejši, skupine, ki se v mestu zadržujejo samo začasno (novi priseljenci, dnevni vozači in študenti), Romi, invalidi in starši samohranilci, med katerimi je nekatere težko vključiti v raziskave s področja kulturne dediščine, je pa njihovo vključenost pomembno zagotoviti.

Avtorici sta proučili, kako se zakonodajni okvir za vključevanje lokalne skupnosti oblikuje in uporablja pri trajnostnem ohranjanju območij kulturne dediščine v Združenem kraljestvu, in tako pridobili pomembne ugotovitve za Burso in Turčijo. Najprej bi bilo treba oblikovati pravne dokumente, ki pojasnjujejo, kako je treba skupnost vključevati v prostorsko urejanje in urbanistično načrtovanje, kot so na primer izjave o vključevanju skupnosti. Poleg tega je pomembno, da se v državah v razvoju, kot je Turčija, oblikovalska orodja zakonsko določijo. Ker se v Turčiji praksa urbanističnega oblikovanja šele razvija, so izkušnje lokalnih oblasti omejene, uporabniki pa so o tej 
Preglednica 3: Priporočila glede procesa in konteksta priprave oblikovalskih smernic za območje Hanlarja v Bursi

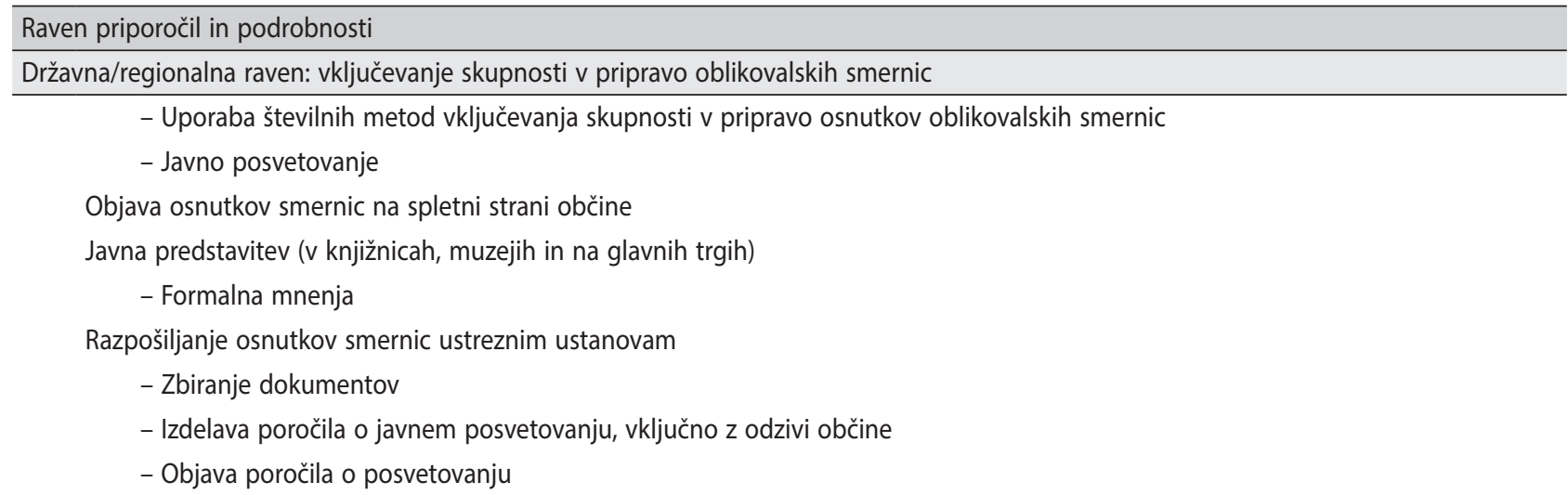
Raven province in mesta: izdelava sistema oblikovalskih usmeritev za Burso

- Cilji, ki se nanašajo na usklajenost s prostorskim kontekstom in merilom v predlagani oblikovalski smernici za Hanlar

Priprava ocene splošnih značilnosti Burse (kot v Bathu)

Priprava oblikovalskih standardov za Burso (kot v Edinburgu)

- Splošna oblikovalska načela je treba oblikovati v pravilnem zaporedju različnih ravni. Za določitev in poenotenje mestne identitete na različnih ravneh je treba območja kulturne dediščine vključiti v nova razvojna območja, zaščititi mestne vedute in robove, izboljšati podobo in berljivost območij kulturne dediščine ter okrepiti in razširiti mrežo zelenih in javnih površin.

- Po mnenju prebivalcev bi bilo treba določiti nove površine za pešce ali pešpoti za izboljšanje povezav med severnim in južnim ter vzhodnim in zahodnim delom mesta, treba bi bilo preprečiti stik pešcev in vozil, izboljšati berljivost turističnih poti in površin ter dostop do podhodov ter urediti nova parkirišča, ki bi bila povezana z javnim prometnim omrežjem.

- Po mnenju lokalnih obrtnikov bi bilo treba določiti največjo dovoljeno višino in maso novih stavb, kar bi ohranilo naravno podobo Burse ter tradicionalno silhueto Hanlarja in njegovo usklajenost s človeškim merilom.

Raven mestnega središča (lokalna raven): izdelava sistema oblikovalskih usmeritev za Burso

- Cilji, ki se nanašajo na usklajenost s prostorskim kontekstom, ravnovesje med javnim in zasebnim prostorom ter prostorsko

kakovost, usklajenost mešane rabe in usklajenost gostote pozidave $z$ vrsto rabe

Izdelava okvira za urbanistično oblikovanje in urejanje javnih prostorov v središču Burse (kot v primeru Liverpoola)

Priprava lokalnega razvojnega okvira za območja kulturne dediščine v Bursi in Cumalıkızıku (kot v primeru Liverpoola)

- Treba je oblikovati splošna oblikovalska načela, na podlagi katerih bi se ustvarili živahni in privlačni kraji, poleg tega pa bi se okrepila tudi lokalna identiteta ter oblikovale razpoznavna urbana oblika in koherentne prostorske ureditve.

- V skladu s pričakovanji lokalnih obrtnikov in mestnih prebivalcev bi bilo treba spodbuditi gradnjo in prostorske ureditve z mešano rabo, zlasti ureditev novih prostorov za kulturne in rekreativne dejavnosti, ki bi omogočali, da bi jih uporabljalo več različnih uporabnikov. V okviru oblikovalskih delavnic bi bilo treba izdelati konceptualne tematske oblikovalske predloge.

Lokalna raven (raven javnih prostorov): izdelava sistema oblikovalskih usmeritev za Burso

- Cilji, ki se nanašajo na dostopnost in pretočnost ter usklajenost gostote pozidave z vrsto rabe

Izdelava okvira za urbanistično oblikovanje in urejanje javnih prostorov v središču Burse (kot v primeru Liverpoola)

Priprava lokalnega razvojnega okvira za območja kulturne dediščine v Bursi in Cumalıkızıku (kot v primeru Liverpoola)

- Za izboljšanje dostopa za pešce v Hanlarju bi bilo treba v skladu z načeli univerzalnega oblikovanja določiti standarde za urejanje ulic, pločnikov, prehodov za pešce in klančin.

- V skladu s pričakovanji lokalnih obrtnikov in mestnih prebivalcev glede ureditve ulic, zaprtih za promet, ki imajo razpoznavne lokalne značilnosti in so dejavne 24 ur na dan, bi bilo treba oblikovati predpise, ki povečajo prostorsko udobje, npr. kvantita-

tivne in kvalitativne standarde za servisne objekte (turistične informacije, stranišča, previjalnice za dojenčke itd) ter ulično opremo (razsvetljavo, površine za sedenje itd).

Raven javnih prostorov in stavb: izdelava sistema oblikovalskih usmeritev za Burso

- Cilji, ki se nanašajo na usklajenost s prostorskim kontekstom ter trajnostno gradnjo in okoljem

Izdelava podrobnih smernic za ohranjanje lokalnih značilnosti in posebnosti Hanlarja (kot v primeru Batha, Liverpoola in Edinburga)

- Za ohranjanje izvirne identitete zgodovinskih stavb in njihovo obnovo v skladu z veljavnimi zahtevami bi bilo treba določiti splošna načela za popravila ter zunanje in notranje spremembe spomeniško zaščitenih stavb. 
tematiki premalo ozaveščeni. $V$ raziskavi sta avtorici uporabili številne metode vključevanja skupnosti in ustreznih akterjev. Če lokalne oblasti javno posvetovanje izvajajo v elektronski obliki, je postopek dostopnejši in hitrejši, pripombe in predlogi pa se lahko učinkoviteje ocenijo. Poleg tega je treba opredeliti tudi metode nadzora in spremljanja ter načine prejemanja povratnih informacij o tem, ali se nasveti v smernicah za Hanlar dejansko tudi izvajajo. Nadzor bi lahko izvajal strokovni odbor enote za upravljanje območij kulturne dediščine v Bursi, uporabo smernic pa bi lahko spodbujali z ozaveščanjem mestnih prebivalcev in lokalnih obrtnikov ter nagrajevanjem primerov uspešnega izvajanja smernic.

Ker je v Turčiji 18 območij, ki so na seznamu Unescove svetovne dediščine, so na področju raziskav kulturne dediščine potrebni sistematski pristopi. Za ta območja bi bilo treba usklajeno izdelati oblikovalske smernice $\mathrm{z}$ načrti za njihovo upravljanje. Raziskava, predstavljena v članku, zato pomembno prispeva k pripravi oblikovalskih smernic, saj pojasnjuje, kako se lahko model participativne priprave oblikovalskih smernic izvaja na območjih kulturne dediščine.

\section{Sibel Polat}

Bursa Uludağ University, Faculty of Architecture, Department of Architecture, Bursa, Turčija

E-naslov: sibelpolat@uludag.edu.tr

H. Özge Tümer Yıldız

Bursa Uludağ University, Faculty of Architecture, Department of Architecture, Bursa, Turčija

E-naslov: ozgetumer@uludag.edu.tr

\section{Zahvala}

Raziskava je bila financirana $\mathrm{v}$ okviru raziskovalnega projekta OUAP(M) - 2012/24, ki je potekal na Univerzi Uludag v Bursi.

\section{Viri in literatura}

Aksoy, A., in Enlil, Z. (2012): Kültürel miras yönetiminde çağdaş yaklaşımlar. V: Aksoy, A., in Ünsal, D. (ur.): Kültürel miras yönetimi, str. 3-28. Eskişehir, Anadolu Üniversitesi Web-Ofset.

BNESC (2005) = Bath \& North East Somerset Council (2005): Streetscape manual. Dostopno na: http://www.bathnes.gov.uk/sites/default/files/ sitedocuments/Planning-and-Building-Control/Planning-Policy/SPDs/ streetscape_manual_adopted.pdf (sneto 27. 2. 2017).

BNESC (2007) = Bath \& North East Somerset Council (2007): Statement of community involvement. Dostopno na: http://www.bathnes.gov.uk/ sites/default/files/sitedocuments/Planning-and-Building-Control/ Planning-Policy/LDFGeneral/StatementofCommunitylnvolvementAdoptedDocument.pdf (sneto 27. 2. 2017).

BNESC (2013) = Bath \& North East Somerset Council (2013): City of Bath World Heritage Site Setting. Dostopno na: https://www.bathworldheritage.org.uk/sites/world_heritage_site/files/heritage/World\%20Heritage\%20Site\%20Setting\%20Supplementary\%20Planning\%20Document. pdf (sneto 27. 2. 2017).
BNESC (2015) = Bath \& North East Somerset Council (2015): Bath Pattern book: Volume 01, Public realm framework. Dostopno na: http://www. bathnes.gov.uk/services/planning-and-building-control/major-projects/ public-realm-and-movement/preparatory-projects (sneto 27. 2. 2017).

BNESC (2018) = Bath \& North East Somerset Council (2018): Supplementary planning documents (SPDs) and other useful guidance. Dostopno na: http://www.bathnes.gov.uk/services/

planning-and-building-control/planning-policy/

supplementary-planning-documents-spds (sneto 19. 7. 2018).

Brombach, K., Simon-Philipp, C., in Kurth, D. (2013): District centre regeneration - A European perspective. Proceedings of the Institution of Civil Engineers Urban Design and Planning. 166(DP4), str. 229-240. DOI: 10.1680/udap.11.00007

Bursa Site Management Unit (2013): Bursa and Cumalıkızık: the Birth of the Ottoman Empire. Bursa, Bursa Metropolitan Municipality. Dostopno na: http://alanbaskanligi.bursa.bel.tr/wp-content/uploads/ unesco-adaylik-dosyasi-ve-ekleri-ingilizce-icin-tiklayiniz.pdf (sneto 19. 7. 2018).

Carmona, M. (2009): Sustainable urban design: Definitions and delivery. International Journal for Sustainable Development, 12(1), str. 48-77.

Carmona, M. (2011): Decoding design guidance. V: Banerjee, T., in Loukaitou-Sideris, A. (ur.): Companion to Urban Design, str. 288-303. London, Routledge.

Carmona, M. (2017): The formal and informal tools of design governance. Journal of Urban Design, 22 (1), str. 1-36.

DOI: $10.1080 / 13574809.2016 .1234338$

CEC (2003) = The City of Edinburgh Council (2003): The Edinburgh standards for urban design. Edinburg. The City Development Department, Planning \& Strategy.

CEC (2015) = The City of Edinburgh Council (2015) Edinburgh street design guidance consultation report.

CEC (2018a) = The City of Edinburgh Council (2018a): Supplementary guidance. Dostopno na: http://www.edinburgh.gov.uk/info/20013/ planning_and_building/64/supplementary_guidance (sneto 27. 2. 2017).

CEC (2018b) = The City of Edinburgh Council (2018b): Edinburgh design guidance . Dostopno na: http://www.edinburgh.gov.uk/downloads/ file/11650/edg_amended_october_2018 (sneto 28. 8. 2018).

CEC (2018c) = The City of Edinburgh Council (2015): Edinburgh street design guidance. Dostopno na: http://www.edinburgh.gov.uk/downloads/file/7165/edinburgh_street_design_guidance (sneto 28. 8. 2018).

CEC (2019) = The City of Edinburgh Council (2019): Listed buildings and conservation areas. Dostopno na: http://www.edinburgh.gov.uk/downloads/file/4510/listed_buildings_and_conservation_areas

(sneto 28. 8. 2018).

Commission for Architecture \& the Built Environment (2003): The councillor's guide to urban design. Dostopno na: http://www.designcouncil. org.uk/sites/default/files/asset/document/ councillors-guide-to-urban-design.pdf (sneto 12. 11. 2017).

Cowan, R. (2002): Urban design guidance: Urban design frameworks, development briefs and master plans. London, Thomas Telford Ltd. DOI: 10.1680/udg.31357

DETR in CABE (2000) = Department of the Environment, Transport and the Regions in Commission for Architecture and the Built Environment (2000): By design, urban design in the planning system: Towards better practice. Dostopno na: https://www.gov.uk/government/uploads/system/uploads/attachment_data/file/7665/158490. pdf (sneto 27. 2. 2017). 
Elnokaly, A. in Elseragy, A. (2013): Sustainable heritage development: Learning from urban conservation of heritage projects in non western contexts. European Journal of Sustainable Development, 2, str. 31-54. DOI: 10.14207/ejsd.2013.v2n1p31

Hassler, U., Algreen-Using, G., in Kohler, N. (2002): Cultural heritage and sustainable development in SUIT. SUIT position paper (3). Dostopno na: http://www.lema.ulg.ac.be/research/suit/download/SUIT5.2c_PPaper.pdf (sneto 12. 11. 2017).

ICOMOS (2005): Threats to world heritage sites 1994-2004: An analysis. Dostopno na: https://www.icomos.org/world_heritage/Analysis\%20 of\%20Threats\%201994-2004\%20final.pdf (sneto 12. 11. 2017).

Križnik, B. (2018): Transformation of deprived urban areas and social sustainability: A comparative study of urban regeneration and urban redevelopment in Barcelona and Seoul. Urbani izziv, 29(1), str. 83-95. DOI: 10.5379/urbani-izziv-en-2018-29-01-003

Lang, J. (1996): Implementing urban design in America: Project types and methodological implications. Journal of Urban Design, 1(1), str. 7-22. DOI: 10.1080/13574809608724368

LCC (2009) = Liverpool City Council (2009): Liverpool maritime mercantile city world heritage site supplementary planning document. Dostopno na: http://liverpool.gov.uk/media/9644/world-heritage-site-spd. pdf (sneto 27. 2. 2017).

LCC (2013) = Liverpool City Council (2013): Statement of Community Involvement. Dostopno na: https://liverpool.gov.uk/council/strategies-plans-and-policies/environment-and-planning/plan-making-in-liverpool/statement-of-community-involvement/ (sneto 27. 2. 2017).

Madanipour, A. (1996): Design of urban space: An inquiry into a socio-spatial process. Chichester, John Wiley and Sons Ltd.

Ministry of Environment and Urbanization (2015): Çevre ve şehircilik Bakanlı̆ınca onaylanacak kentsel tasarım projelerinin hazırlanmasına ve değerlendirilmesine Ilişkin yönerge. Dostopno na: https://kms.kaysis.gov. tr/Home/Goster/131263 (sneto 28. 8. 2019).

Ministry of Environment and Urbanization in Mimar Sinan Fine Arts University (2016): Kentsel tasarım rehberleri, cilt 1. Dostopno na: http:// webdosya.csb.gov.tr/db/mpgm/editordosya/file/Kentsel\%20Tasarim/ Kentsel\%20Tasarim\%20Rehberleri/KENTSEL\%20TASARIM\%20REHBERLERI_Cilt1.pdf (sneto 27. 2. 2017).

MPWS (2010) = Ministry of Public Works and Settlements (2010): Bütünleşik kentsel gelişme stratejisi ve eylem planı. (KENTGES) Dostopno na: https://webdosya.csb.gov.tr/db/kentges/editordosya/kentges_ tr.pdf (sneto 28. 8. 2019).

Nasser, N. (2003): Planning for urban heritage places: Reconciling conservation, tourism, and sustainable development. Journal of Planning Literature, 17(4), str. 467-479. DOI: 10.1177/0885412203017004001

Özcan, K. (2009): Sürdürülebilir kentsel korumanın olabilirliği üzerine bir yaklaşım önerisi: Konya tarihi kent merkezi örneği. ODTÜ Mimarlık Fakültesi Dergisi, 26(2), str. 1-18. DOI: 10.4305/metu.jfa.2009.2.1

Polat, S., Tümer Yıldız, H. Ö., in Dostoğlu, N. (2018): A user-oriented urban design guide model for cultural heritage sites: The case of Bursa Khans area. Megaron, 13(4), str. 584-596. DOI: 10.5505/megaron.2018.32043

Punter, J. (2007): Developing urban design as public policy: Best practice principles for design review and development management. Journal of Urban Design, 12(2), str. 167-202. DOI: 10.1080/13574800701306195

Rezafar, A., in Turk, S. S. (2018): Urban design factors involved in the aesthetic assessment of newly built environments and their incorporation into legislation: The case of Istanbul. Urbani izziv 29(2), str. 83-95. DOI: 10.5379/urbani-izziv-en-2018-29-02-002
Royal Town Planning Institute in Consultation Institute (2005): Guidelines on effective community involvement and consultation. Dostopno na: http://www.rtpi.org.uk/media/6313/Guidlelines-on-effective-community-involvement.pdf (sneto 27. 2. 2017).

Scottish Government (2010): Planning advice note 3/2010 Community engagement. Dostopno na: http://www.gov.scot/Publications/2010/08/30094454/12 (sneto 27. 2. 2017).

Tiesdell, S., Oc, T., in Heath, T. (1996): Revitalizing historic urban quarters. London, Butterworth-Heinemann.

Van Oers, R. (2010): Managing cities and the historic urban landscape initiative - an introduction. V: Van Oers, R., in Haraguchi, S. (ur.): Managing Historic Cities; World Heritage Papers, 27, str. 7-17. Pariz, World Heritage Centre. Dostopno na: http://whc.unesco.org/documents/ publi_wh_papers_27_en.pdf (sneto 10. 4. 2017).

Von Hausen, M. A. (2013): Dynamic urban design. Bloomington, IN, iUniverse.

Yeang, L. D. (2000): Urban design compendium. Dostopno na: http:// www.queenelizabetholympicpark.co.uk/-/media/lldc/local-plan/local-plan-examination-documents/other-strategy-papers/s34-urbandesign-compendium.ashx?la=en (sneto 27. 2. 2017). 